ADVANCE RESEARCH JOURNAL OF SOCIAL SCIENCE
$\begin{gathered}\text { ACASE } \\ \text { Volume 6 } 6 \text { Issue } 1 \mid \text { June, } 2015 \mid 87-90\end{gathered}$
DOI: 10.15740/HAS/ARJSS/6.1/87-90

\title{
Evaluate the management and regulatory capacity of district hospital Tumkur
}

\section{N. Kumara* and Nehal A. Farooquee}

Department of Extension and Development Studies, Indira Gandhi National Open University, NEW DELHI (INDIA)

(Email: nkumar278@gmail.com)

\section{ARTICLE INFO :}

Received : 10.07 .2014

Accepted : 22.05.2015

\section{KEY WORDS :}

Management, Regulatory capacity, Resources, Men, Materials, Management

\section{HOW TO CITE THIS ARTICLE :}

Kumara, N. and Farooquee, Nehal A. (2015). Evaluate the management and regulatory capacity of district hospital Tumkur. Adv. Res. J. Soc. Sci., 6 (1) : 8790.

*Author for correspondence

\begin{abstract}
A study was conducted in Tumkur District Hospital of Karnataka state to evaluate the Management and Regulatory Capacity to how Resources like men, money, materials are used effectively to achieve goals / objectives. A sample of 100 respondents was selected randomly from Specialists, Ministerial Staff, Staff Nurse, technical / supporting staff and group D staff of 20 each. 87 per cent of staff expressed the good availability of funds (money) and 13 per cent not knowing the fund availability. There is a vacancy of 118 posts $(35.65 \%)$ against the 331 sanctioned post and 66 equipments $(13 \%)$ out of 508 were not working as a result patients treated reduced to 328 in 2013-14 with a total of 251118 patients against the total patients treated in 2012-13 were 250790 .
\end{abstract}

